\title{
FEEDING OF JUVENILE TWAITE SHAD \\ (ALOSA FALLAX LACÉPĖDE, 1803) \\ IN THE ELBE ESTUARY.
}

\author{
S. OESMANN, R. THIEL
}

University of Hamburg, Institute of Hydrobiology und Fishery Science, Elbelab, Große Elbstraße 268, D-22767 HAMBURG, Germany.

Reçu le 15 octobre 2000

Accepté le 22 janvier 2001

Received 15 October, 2000

Accepted 22 January, 2001

\begin{abstract}
Seasonal, diurnal and size-dependent trends of food composition, prey selection and daily ration of juvenile twaite shad were investigated in the Elbe estuary. Juvenile twaite shad were caught for diet analysis with framed gape stow nets in the mesohaline region of the Elbe estuary in April, July and August 1993. Copepods, mysids and fish were identified as main food items of juvenile twaite shad. In August, the importance of mysids and fish as main prey organisms increased with increasing total length of twaite shad, whereas the proportion of copepods decreased. During night fishes were consumed to a lesser extent than during day. Insects were mainly eaten during night. In the early morning copepods were main food items. Juvenile twaite shad preferred the mysidacean Mesopodopsis slabberi and the sprat Sprattus sprattus. Cladocerans were ingested corresponding to their availability, whereas all other food items were avoided. Daily ration according to WINBERG (1956) showed peak values in spring and summer and decreased during the following season. The maximum daily ration of about $45 \%$ of body wet weight was calculated in May. Daily ration decreased with increasing age of juvenile twaite shad.
\end{abstract} daily ration.

Key-words : twaite shad, Elbe estuary, Alosa fallax, food composition, selection,

\section{RÉGIME ALIMENTAIRE DES JUVÉNILES D'ALOSE FEINTE (ALOSA FALLAX LACÉPĖDE, 1803) DANS L'ESTUAIRE DE LA RIVIÈRE ELBE.}

\section{RÉSUMÉ}

L'objectif de cette étude est d'examiner le régime alimentaire saisonnier et journalier en fonction de la taille, ainsi que la sélectivité alimentaire et la ration journalière chez les juvéniles d'alose feinte, issus de l'estuaire de la rivière Elbe. La capture des individus examinés à l'aide de filet à armature s'est déroulée en avril, juillet et août 1993 dans le domaine mesohalin estuarien. Copépodes, mysidacés et poissons ont été identifiés comme étant les composantes alimentaires principales. La consommation en poissons et en mysidacés augmente avec l'accroissement de la longueur totale. En août dans le même temps, on observe une diminution de la consommation en copépodes. Les poissons représentent la nuit une moindre part dans le bol alimentaire par rapport au jour. Les plus fortes proportions de copépodes dans le bol alimentaire ont été observées au matin très 
tôt et l'après-midi. Une sélection positivement significative a été calculée pour les mysidacés Mesopodopsis slabberi et les sprats Sprattus sprattus et les cladocères ont été consommés selon l'offre. Pour les autres composantes alimentaires, un indice de sélection négativement significatif a été calculé. La ration alimentaire d'après WINBERG (1956) est caractérisée par une valeur élevée au printemps et en été et une diminution au cours des autres saisons. La ration journalière maximale avec une valeur de $45 \%$ a été observée en mai 1992. Avec l'âge la ration alimentaire des juvéniles d'alose feinte diminue.

Mots-clés : alose feinte, Alosa fallax, estuaire de la rivière Elbe, régime alimentaire, sélection, ration journalière.

\section{INTRODUCTION}

Twaite shad (Alosa fallax Lacépède, 1803) accounts for ca. $17 \%$ of the total fish abundance and $5 \%$ of the total fish biomass in the tidal Elbe River, Germany (THIEL et al., 1995). Highest abundance and biomass of twaite shad occurred in the Elbe River from May to September (THIEL et al., 1996).

The spawning period of the twaite shad stock of the Elbe will usually last from the beginning of May to the middle of June (HASS, 1968). Individuals migrating into the Elbe for spawning are mainly between 2 and 7 years old and have total lengths between 30 and $50 \mathrm{~cm}$ (HASS, 1965). Each specimen of the Elbe stock may take part in several annual spawning runs during its life. Males mature after their second to fifth winter, females after their third to sixth. Female twaite shad specimens of the Elbe stock will each produce 50000 to 200000 eggs (HASS, 1965). Twaite shad spawn upstream of the upper boarder of brackish water (EHRENBAUM, 1894). During the last decade, in upstream displacement of the main spawning grounds of twaite shad was observed in the Elbe River (THIEL et al., 1996) which could be attributed to the upstream shift of the upper border of brackish water due to deepening of the shipping canal (ARGE ELBE, 1992). The improving water quality since 1990 (REINCKE et al., 1992) could be a second reason for the upstream shift of the upper border of the spawning site. Currently, twaite shad spawns upstream of stream-km 645 but downstream of the harbour area of the city of Hamburg.

The eggs of the twaite shad have, on an average, diameters of $3.85 \mathrm{~mm}$ and may be whirled up to a height of $9.5 \mathrm{~m}$ above the bottom by current (HASS, 1968), although, most of them are to be found in the layer between the bottom and a height of $2.5 \mathrm{~m}$ above it. The larvae hatch with total lengths of $4.25 \mathrm{~mm}$ after 3 - 5 days and finish their metamorphosis having total lengths of between 24 and $29 \mathrm{~mm}$ (EHRENBAUM, 1894). Juvenile twaite shad of age group 0 start their downstream migration to the North Sea in June (THIEL et al., 1996). Total length of age-0 twaite shad is about $10 \mathrm{~cm}$ and of age-1 twaite shad about $20 \mathrm{~cm}$ at the end of the first or second year of life, respectively. The proportion of twaite shad with regard to total annual fish production in the Elbe estuary amounted to $1.1 \%$ in 1992 (THIEL, 2001).

However, like in the case of other juvenile clupeid fishes, the importance of the food consumption of juvenile twaite shad has not been taken into account in calculations of flow of matter and energy for a long time (ARRHENIUS and HANSSON, 1993). HEWETT and STEWART (1989) while investigating Alosa pseudoharengus in Lake Michigan stated that especially the age group 0 can contribute a large proportion to the populations total consumption. In that lake, young-of-the-year consumption amounted to about $50 \%$ of the annual total consumption of this species.

Information concerning the food composition of European shads, especially of juvenile twaite shad are very rare. Although there exist a few studies regarding the food composition of twaite shad (e.g. APRAHAMIAN, 1989 ; ASSIS et al., 1992), e.g. no data 
about the daily ration of juvenile twaite shad have been published yet. Therefore, the aims of this study were :

(I) to analyse the seasonal, diurnal and size-dependent changes of the food composition of juvenile twaite shad,

(II) to detect patterns of their prey selection,

(III) to calculate the daily ration based on field samples in the Elbe estuary, Germany.

\section{MATERIAL AND METHODS}

\section{Study area}

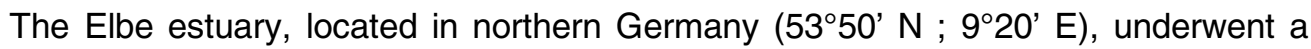
persisting antropogenous intrusion since the first centuries of our calendar (PALUSKA, 1992). Nowadays, it is almost entirely channelised (Figure 1).

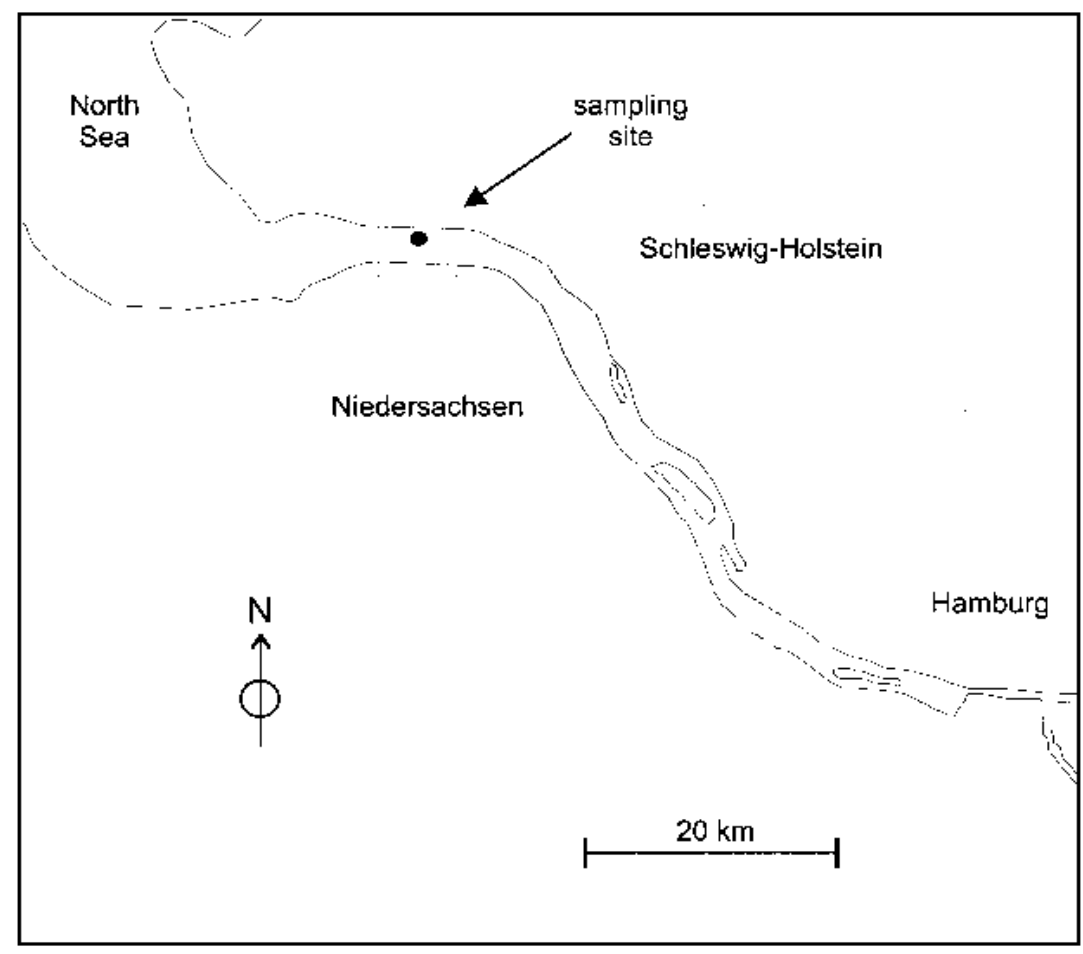

\section{Figure 1}

Map of the Elbe estuary showing the sampling site.

\section{Figure 1}

Carte de l'estuaire de la rivière Elbe avec l'aire échantillonnée. 
The estuary is subject to strong tidal action. The tidal range is more than $3 \mathrm{~m}$ between low and high water. KIES et al. (1992) described the spatial distribution of the salinity gradient. Further details regarding environmental conditions in the Elbe estuary are given by THIEL et al. (1995). Main structuring forces of the fish community of the Elbe estuary are salinity and temperature. Twaite shad is one of the most important species here, especially during summer (THIEL et al., 1996).

\section{Sampling}

The sampling of twaite shad took place in the mesohaline main stream region of the lower tidal Elbe River at stream kilometer 692, close to the city of Brunsbüttel (Figure 1). The mean water depth at this station was $11.5 \mathrm{~m}$. Sampling was performed using two different types of framed gape stow nets in April, July and August 1993. In April and August 1993 juvenile twaite shad were collected for ca. $4 \mathrm{~h}$ on both flood and ebb tides using a commercial stow net vessel with a net square opening of $90 \mathrm{~m}^{2}$ and $8 \mathrm{~mm}$ cod end (THIEL et al., 1995). Additional stow net catch data for 1992 and 1993 were taken from THIEL et al., $(1995,1996)$ to complete the databasis for the calculation of daily ration. Sampling involved firstly anchoring the boat and then placing the stow net at its right side so that its opening faced the direction of the water flow. Three mechanical flowmeters (Hydrobios) were placed in the opening of the net to determine the volume of water passing through the net. During each haul ca. $1000000 \mathrm{~m}^{3}$ of water passed the net. Water temperature and salinity were recorded at the beginning and end of each $4 \mathrm{~h}$ sampling period using a Wissenschaftliche Technische Werkstätten LF 196 meter.

To determine the diurnal pattern of food consumption and the pattern of prey selection one 24-hour fishery was carried out at the $08^{\text {th }}$ and $09^{\text {th }}$ of July 1993 . For that purpose, and to allow easy lifting and emptying, a smaller framed stow net according to NELLEN et al. (1987) was used near the water surface between 2 and $4 \mathrm{~m}$ depth from board of an anchored swimming platform. The meshsize of this net was $1.8 \mathrm{~mm}$ in the cod end. It had a total length of $4.5 \mathrm{~m}$. The net was linked to a robust allumine, profile frame. It had a net opening of $4 \mathrm{~m}^{2}$, which was fixed in vertical position by the help of a stern fin. The low mesh size of this net enabled to catch twaite shads and larger food organisms e.g. fish and decapods, simultaneously.

The net was passively exposed to the tidal current by a crane. During the 24-hour period overall 18 hauls were performed with a mean duration of ca. 20 minutes. The mean current during the hauls was $1.13 \mathrm{~m} . \mathrm{s}^{-1}$ and the mean filtrated water volume amounted to ca. $5400 \mathrm{~m}^{3}$. Simultaneously, water temperature and salinity were measured using a multiprobe (Meereselektronik, model ME VDT 24). The water flow through the net was estimated using a mechanical flowmeter (General Oceanics, model 438 110).

All samples from the stow nets were preserved in $8 \%$ borax-buffered formaldehyde solution in filtrated Elbe water, since according to HAY (1982), fixation shrinkage as well as its salinity dependent range are relatively low at this formaldehyde concentration. The species determination of fish larvae and juveniles was performed according to MUUS and DAHLSTRÖM (1965) and DIECKWISCH (1987) after a duration of the formaldehyde fixation of at least 3 months. Total length of all individuals was measured to the millimeter below.

More details about the sampling procedure and about the day and night pattern of the catches are given in OESMANN (1994). As reported by THIEL and POTTER (2001) no differences between flood and ebb catches were observed. 


\section{Diet analysis}

A total of 145 juvenile individuals of twaite shad were analysed. For the diet analysis, the stomach contents were preserved into $96 \%$ ethanol. Food organisms were determined according to HARDING and SMITH (1974), KIEFER and FREYER (1978), KLAUSNITZER et al. (1978), MEHNER (1990), SCOURFIELD and HARDING (1966), SMITH (1977) and STRESEMANN (1986). Non digestible items like sand and parasitic nematods and trematods were excluded from further analysis. All digestible food items were counted. All larger food organisms (e.g. mysids) were measured. From frequently occurring small food organisms subsamples containing at least 50 organisms were measured.

\section{Calculations}

\section{Back-calculation of food biomass}

Based on the lengths measurements the food biomass of the food items was backcalculated. Due to the digestive process in some cases only fragments of food organisms were found in the stomachs. In those cases, the total lenghts of food organisms were calculated using fragment - total length regressions. Then, the back-calculation of the consumed food biomass was performed with the help of total length - weight relationships. In the case of detritus, the volume of the particles was estimated. The back-calculation of the weight of detritus particles was then performed using the volumes and density values for detritus particles. The regressions and density values were taken from OESMANN (1994).

\section{Prey selection}

The electivity index of IVLEV (1961) was used to estimate the prey selection with regard to different food items. Selectivity was calculated as :

$$
E_{i}=\left(r_{i}-p_{i}\right) /\left(r_{i}+p_{i}\right)
$$

With : $E_{\mathrm{i}}=$ electivity index,

$r_{i}=$ relative abundance of the food item $i$ in the stomach,

$p_{i}=$ relative abundance of the food item $i$ in the environment.

$E_{i}$ can reach values between -1 and +1 . Positive values indicate a preference for the relevant prey by the investigated predator, negative values indicate an avoidance. The level of significance is assumed to be \pm 0.3 (LAZZARO, 1987). The estimation of the relative abundances of the larger food items in the environment based on catches performed simultaneously with the catches of twaite shad. The $p_{i}$-values for mesozooplankton were taken from KÖPCKE and KAUSCH (1996) and KÖPCKE (pers. comm.) which were also estimated simultaneously with the catches of twaite shad. During the calculation the electivity indices for the main food items were firstly calculated for each haul separately. Based on these values, the averages and their confidence limits were calculated for a 24 hour period from the $08^{\text {th }}$ until the $09^{\text {th }}$ of July 1993. 
Daily ration according to WINBERG (1956)

The determination of the daily ration according to WINBERG (1956) was performed with a bioenergetic model using the formula :

$$
R[\%]=1.25 *(G+A)
$$

With $: R=$ daily ration in \% fish weight,

$\mathrm{G}=$ mean growth per fish and day in \% fish weight,

$A=$ daily demand of routine metabolism in $\%$ fish weight.

The factor 1.25 expresses WINBERG's (1956) basic assumption that approximately $80 \%$ of the ingested food energy will be transformed into usable energy for the fish, while the remaining $20 \%$ will be spent on excretion (15\%) and egestion (5\%). Growth data were taken from THIEL et al. (1996).

Routine metabolism A was calculated according to :

$$
\mathrm{A}[\%]=\frac{a^{*} M^{k} * b^{*} c^{*} t^{*} 100}{q^{*} M}
$$

With : $\mathrm{a}=\mathrm{O}_{2}$ - demand $\left[\mathrm{ml}^{*} \mathrm{~g}^{-1}{ }^{*} \mathrm{~h}^{-1}\right]$,

$\mathrm{M}=$ mean fish weight $[\mathrm{g}]$,

$\mathrm{k}=$ coefficient of the dependance of the $\mathrm{O}_{2}$ - demand from the fish weight,

$\mathrm{b}=$ coefficient of metabolic activity,

$\mathrm{c}=0.0048$ (includes the oxicaloric coefficient of $4,8 \mathrm{cal} . \mathrm{ml} \mathrm{O}_{2}^{-1}$ and an average energy content of fish of 1000 cal.g $\mathrm{g}^{-1}$ wet weight),

$\mathrm{t}=$ time interval $[\mathrm{d}]$,

$q=$ coefficient that takes into account the influence of the temperature on the metabolic rate $(\mathrm{KROGH}, 1916)$.

Values for a (0.399) and $\mathrm{k}(0.78)$ at $20^{\circ} \mathrm{C}$ were taken from STEWART and BINKOWSKI (1986) for Alosa pseudoharengus. Weight (M) and corresponding time (t) data were used from THIEL et al. (1996). The coefficient of metabolic activity (b) was set to 2 applying the Winberg-II-level (MANN, 1978).

\section{Daily ration according to EGGERS (1979)}

For verification purposes of the daily ration values calculated with the WINBERGmethod one reference value was produced using the method of EGGERS (1979) as follows :

$$
R[\%]=-r * S * 24
$$

Where $: R=$ daily ration in $\%$ fish weight,

$r=$ stomach evacuation rate [\% fish weight $\left.* h^{-1}\right]$,

$\mathrm{S}=$ mean stomach content in $24 \mathrm{~h}[\%$ fish weight],

$24=$ factor to produce daily values.

For stomach evacuation rate of twaite shad, a formula published from BLAXTER and HUNTER (1982) for planctivorous, juvenile clupeid fishes was applied, where :

$$
r=-0,0132+0,0316 \ln \mathrm{T}-0,0403(\ln \mathrm{T})^{2}
$$

with $: \mathrm{T}=$ temperature $\left({ }^{\circ} \mathrm{C}\right)$. 


\section{RESULTS}

\section{General patterns of food composition}

A total of 25 different food components were found in the diet of juvenile twaite shad (Table I). These food items were grouped into 10 main categories : fish, mysids, other malacostracs, cladocerans, copepods, insects, acarids, unidentified eggs, plants and detritus. Taking into account all calculated values of relative numbers and biomass of prey, copepods, mysids and fish were the main food items of juvenile twaite shad in the Elbe estuary (Table I).

\section{Table I}

Food composition of juvenile twaite shad in the Elbe estuary in 1993.

\section{Tableau I}

Le régime alimentaire des juvéniles d'alose feinte dans l'estuaire de la rivière Elbe en 1993.

\begin{tabular}{|c|c|c|c|c|c|c|c|c|c|c|c|c|}
\hline Month & & Ap & ril & & & Ju & uly & & & Aug & yust & \\
\hline Age group & & 1 & 1 & & & 0 & & & & c & 0 & \\
\hline $\begin{array}{l}\text { Length group }(\mathbf{m m}) \\
\text { Number of investigated fish }\end{array}$ & 80 & -99 & $\begin{array}{r}100-1 \\
9\end{array}$ & 119 & & -49 & & $\begin{array}{l}-59 \\
51\end{array}$ & & $\begin{array}{l}-79 \\
12\end{array}$ & & $\begin{array}{l}-99 \\
6\end{array}$ \\
\hline $\begin{array}{l}\text { Number (N) and Biomass (B) of } \\
\text { food items (\%) }\end{array}$ & $N(\%)$ & $\mathrm{B}(\%)$ & $N(\%)$ & $\mathrm{B}(\%)$ & $N(\%)$ & B (\%) & $N(\%)$ & $\mathrm{B}(\%)$ & $N(\%)$ & B (\%) & $N(\%)$ & B (\%) \\
\hline $\begin{array}{l}\text { FISH } \\
\text { Sprattus sprattus }\end{array}$ & & & & & $\begin{array}{l}\mathbf{0 , 7} \\
0,4\end{array}$ & $\begin{array}{l}\mathbf{2 7 , 3} \\
26,8\end{array}$ & $\begin{array}{l}\mathbf{8 , 4} \\
5,7\end{array}$ & $\begin{array}{l}\mathbf{6 0 , 7} \\
45,7\end{array}$ & 0,8 & 7,0 & 35,6 & 86,5 \\
\hline Osmerus eperlanus & & & & & 0,3 & 0,5 & 2,7 & 15,0 & 0,2 & 0,6 & 14,8 & 26,7 \\
\hline Pomatoschistus spec. & & & & & & & & & 0,6 & 6,4 & 20,8 & 59,8 \\
\hline MYSIDS & & & & & 0,7 & 6,9 & 12,6 & 20,9 & 98,9 & 92,9 & $\mathbf{5 5 , 7}$ & 12,6 \\
\hline Neomysis integer & & & & & 0,1 & 0,8 & 1,7 & 2,3 & 0,2 & 0,1 & 10,7 & 1,4 \\
\hline Mesopodopsis slabberi & & & & & 0,6 & 6,1 & 10,9 & 18,6 & 98,7 & 92,8 & 45,0 & 11,2 \\
\hline $\begin{array}{l}\text { OTHER MALACOSTRACS } \\
\text { Corophium spec. }\end{array}$ & & & & & $<0,1$ & 0,1 & 2,7 & 0,4 & & & $\begin{array}{l}1,4 \\
1,4\end{array}$ & $\begin{array}{l}0,2 \\
0,2\end{array}$ \\
\hline Crangon crangon & & & & & $<0,1$ & 0,1 & 2,7 & 0,4 & & & & \\
\hline CLADOCERANS & 2,2 & 1,1 & 0,1 & 1,4 & 0,8 & $<0,1$ & 2,7 & $<0,1$ & & & 1,3 & $<0,1$ \\
\hline Daphnia spec. & & & 0,1 & 1,4 & 0,7 & $<0,1$ & 1,7 & $<0,1$ & & & 1,3 & $<0,1$ \\
\hline Unidentified & 2,2 & 1,1 & & & & & & & & & & \\
\hline Ephippia & & & & & 0,1 & $<0,1$ & 1,0 & $<0,1$ & & & & \\
\hline COPEPODS & 92,9 & 22,5 & $\begin{array}{l}99,8 \\
99\end{array}$ & 66,5 & 89,0 & $\mathbf{3 , 3}$ & 51,7 & 0,4 & & & & \\
\hline $\begin{array}{l}\text { Eurytemora affinis } \\
\text { Cyclops spec. }\end{array}$ & 33,7 & 22,2 & 4,1 & 55,3 & 89,0 & 3,3 & $\begin{array}{r}51,5 \\
0,2\end{array}$ & $\begin{array}{r}0,4 \\
<0,1\end{array}$ & & & & \\
\hline Copepod eggs & 59,2 & 0,3 & 95,7 & 11,2 & & & & & & & & \\
\hline INSECTS & & & $<0,1$ & $<0,1$ & 6,9 & 51,3 & 6,2 & 17,4 & 0,3 & 0,1 & 4,7 & 0,6 \\
\hline Diptera & & & & & 0,2 & 0,9 & & & 0,3 & 0,1 & & \\
\hline Diptera larvae & & & & & 0,1 & 0,5 & & & & & & \\
\hline Nematocera & & & & & 1,6 & 33,4 & 5,0 & 16,7 & & & & \\
\hline Trichoptera & & & $<0,1$ & $<0,1$ & & & & & & & & \\
\hline Homoptera & & & & & $<0,1$ & 0,2 & & & & & & \\
\hline Unidentified & & & & & 0,2 & 1,2 & 0,5 & 0,4 & & & & \\
\hline Fragments & & & & & 4,7 & 15,1 & 0,7 & 0,3 & & & 4,7 & 0,6 \\
\hline ACARIDS & & & & & 0,4 & 0,5 & & & & & & \\
\hline UNIDENTIFIED EGGS & 2,2 & 0,9 & & & 0,3 & $<0,1$ & 15,5 & 0,1 & & & & \\
\hline PLANTS & 1,6 & 70,2 & $<0,1$ & 4,8 & 0,1 & 9,4 & 0,2 & $<0,1$ & & & 1,3 & 0,1 \\
\hline Macrophyte fragments & 1,6 & 70,2 & & & & & & & & & 1,3 & 0,1 \\
\hline Seeds & & & $<0,1$ & 4,8 & 0,1 & 9,4 & 0,2 & $<0,1$ & & & & \\
\hline DETRITUS & 1,1 & 5,3 & $<0,1$ & 27,3 & 1,0 & 1,1 & & & & & & \\
\hline
\end{tabular}




\section{Seasonal changes of food composition}

The food composition of juvenile twaite shad was significantly different in terms of both numbers and biomass proportions between April, July and August 1993 (KruskalWallis H-Test, $\mathrm{p}<0.05$ ).

In April 1993 the diet of twaite shad was dominated by copepods including their egg stages (Figure 2 ; Table I). Overall, the contents of the stomachs in numbers consisted of $96 \%$ copepod eggs, $4 \%$ copepodids and less than $1 \%$ other items. Although copepods also dominated the biomass proportions of ingested food items in April, remarkable proportions could be attributed to detritus (26\%), plants (10\%) and cladocerans $(1 \%$, Figure 2).

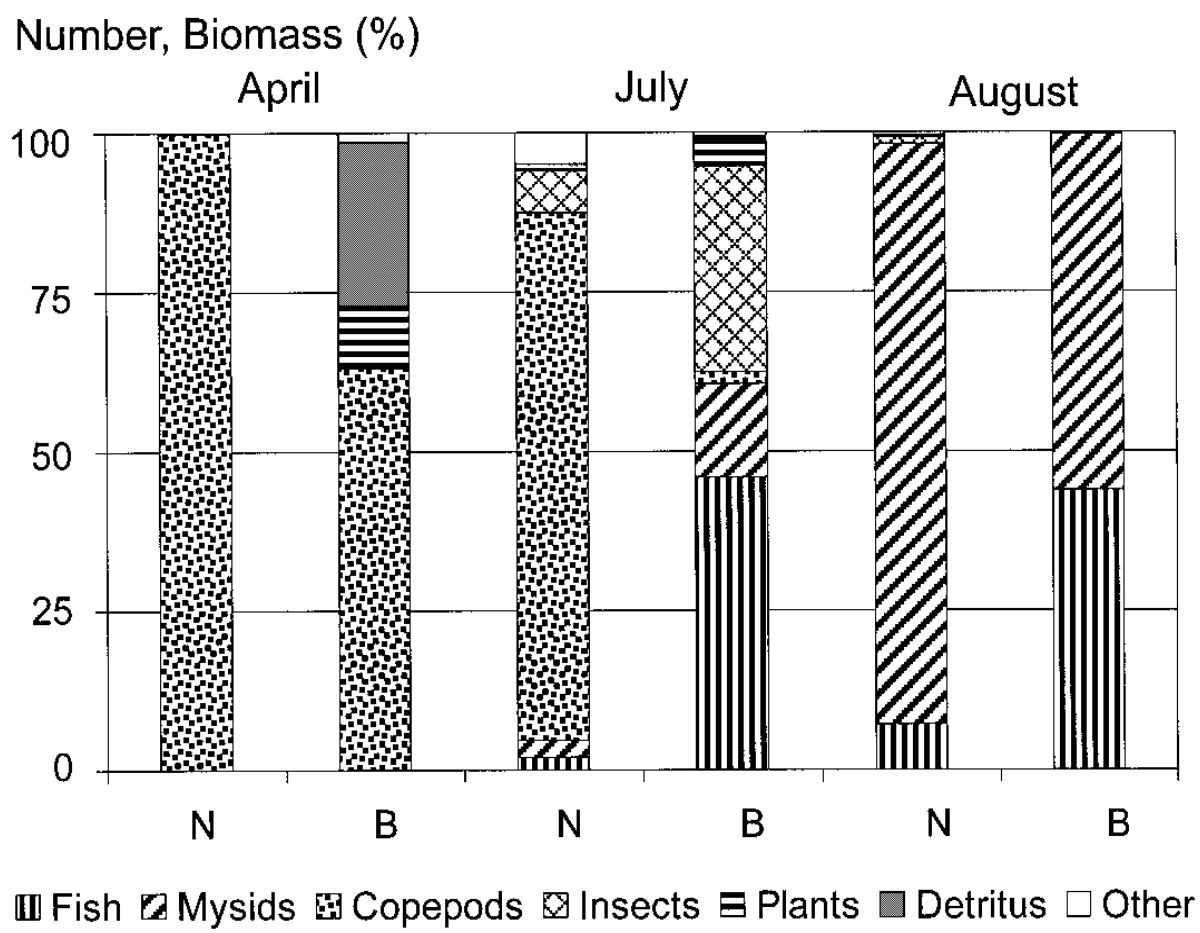

\section{Figure 2}

Seasonal changes of main prey items in the diet of juvenile twaite shad in the Elbe estuary in 1993 ; left column (N) - relative numbers (\%), right column (B) relative biomass $(\%)$.

\section{Figure 2}

Variation saisonnière de la composante alimentaire principale des juvéniles d'alose feinte en 1993 ; N = Abondance (\%), B = Biomasse (\%).

In July copepods made the main contribution by numbers, i.e. $83 \%$ to the diet of juvenile twaite shad. All other food categories (insects $7 \%$, mysids $3 \%$, fish $2 \%$, detritus $1 \%$, other $4 \%$ ) contributed less than $8 \%$ to the number of diet items during this time of the year. The biomass proportions were clearly dominated by fish (46\%), followed by insects (32\%), mysids (15\%), plants (4\%) and copepods (2\%).

High numbers $(\mathrm{N})$ and biomasses $(\mathrm{B})$ of mysids $(\mathrm{N}=91 \% ; \mathrm{B}=56 \%)$ and fish $(\mathrm{N}=7 \% ; \mathrm{B}=44 \%)$ were consumed by age-0 twaite shad in August (Figure 2). 


\section{Size-dependent trends of food composition}

A statistical significance of a size-dependent trend of food consumption was only estimated for the number proportions in August 1993 (Mann-Whitney U-test, $p<0.05$ ). However, tendencially juvenile twaite shad preyed on larger prey with increasing body size also in July (Table I). In July, for instance, the importance of mysids (Neomysis integer, Mesopodopsis slabberi) and fish (Sprattus sprattus, Osmerus eperlanus and Pomatoschistus spec.) as main prey organisms tended to increase with increasing total length of twaite shad, whereas the proportion of copepods decreased (Figure 3). This trend was much more distinct with regard to the biomass proportions than concerning the number proportions of ingested food items. In August, larger twaite shads preferred to consume fish and Neomysis integer, whereas the prey proportions of Mesopodopsis slabberi decreased.

A)

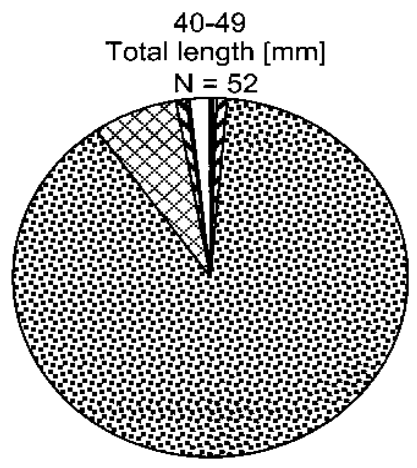

B)

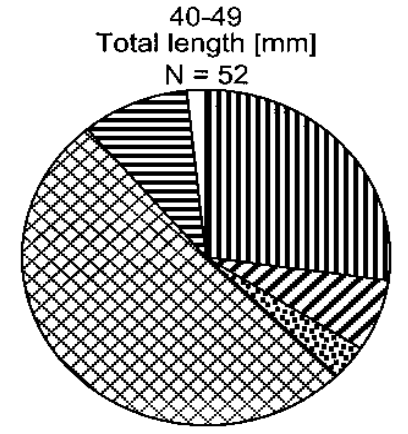

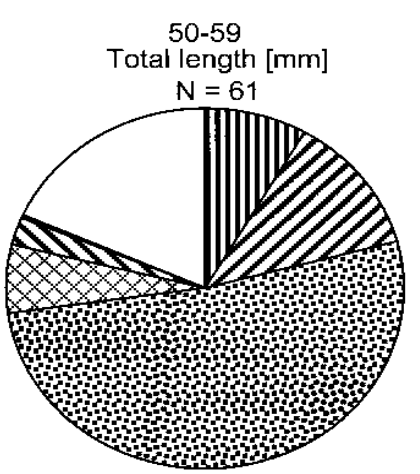

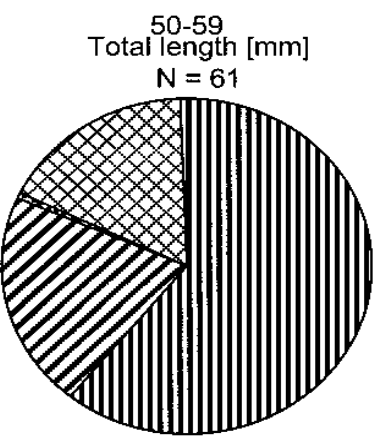

图 Copepods
EPlants
Mysids

$\mathbf{\Delta C l a d o c e r a n s}$

\section{Figure 3}

Food composition of two different length groups of age-0 twaite shad in the Elbe estuary in July 1993 - A) relative numbers (\%), B) relative biomass (\%).

\section{Figure 3}

Régime alimentaire de deux différentes classes de taille d'alevins d'alose feinte de l'estuaire de la rivière Elbe en juillet 1993; $A=$ Abondance (\%), $B=$ Biomasse (\%). 


\section{Diurnal course of food composition in July}

The number proportions of the ingested food items differed between day and night (Mann-Whitney U-test, $\mathrm{p}<0.05$ ). During night fishes were consumed to a lesser extent than during day (Figure 4). In samples taken between 21:30 and 0:30 pm the food was dominated by insects. In the early morning, higher amounts of copepods, especially of Eurytemora affinis occurred in the stomachs of twaite shad (Figure 4). Mysids dominated in the prey both in the evening and morning.

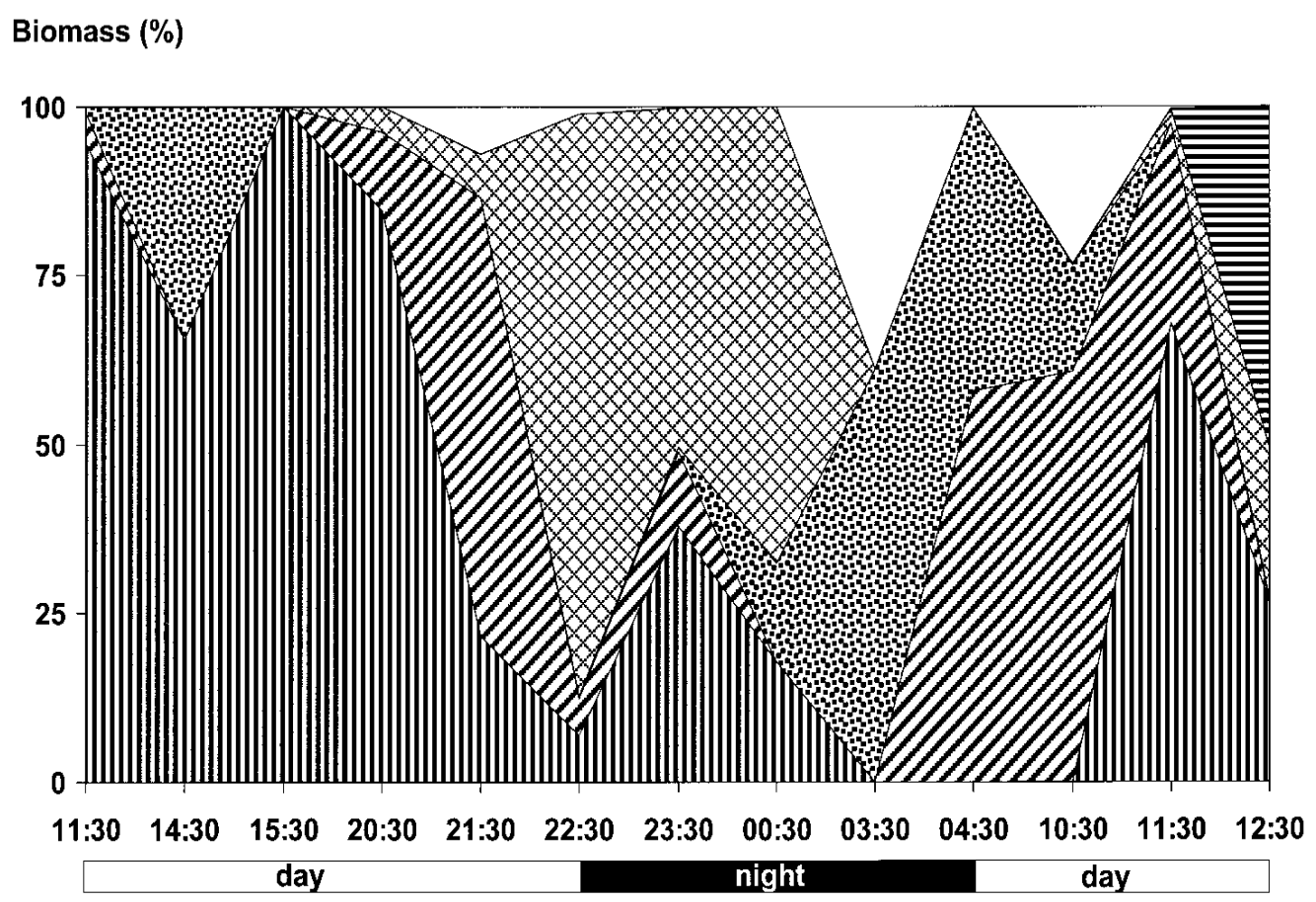

III Fish $\square$ Mysids Copepods $\otimes$ Insects $\mathbf{\Delta}$ Cladocerans EPlants $\square$ Other

\section{Figure 4}

Diurnal course of food biomass (\%) of age-0 twaite shad in the Elbe estuary during a $24 \mathrm{~h}$ period between $8^{\text {th }}$ and $9^{\text {th }}$ July 1993.

\section{Figure4}

Rythme jour/nuit du régime alimentaire (Biomasse \%) d'alose feinte de classe d'âge 0 du 8 au 9 juillet 1993.

\section{Prey selection in July}

A daily mean electivity index of more than $+0,3$ according to IVLEV (1961) demontrates a preference of twaite shad for Mesopodopsis slabberi and for larval Sprattus sprattus (Figure 5). Cladocerans were ingested corresponding to their availability. Negative selectivity indices lower than - 0,3 indicated that Osmerus esperlanus, gobiids, C. crangon, $N$. integer and copepods were avoided (Figure 5 ). The lowest electivity value was calculated for gobiids $(\mathrm{Ei}=-0.8)$. 


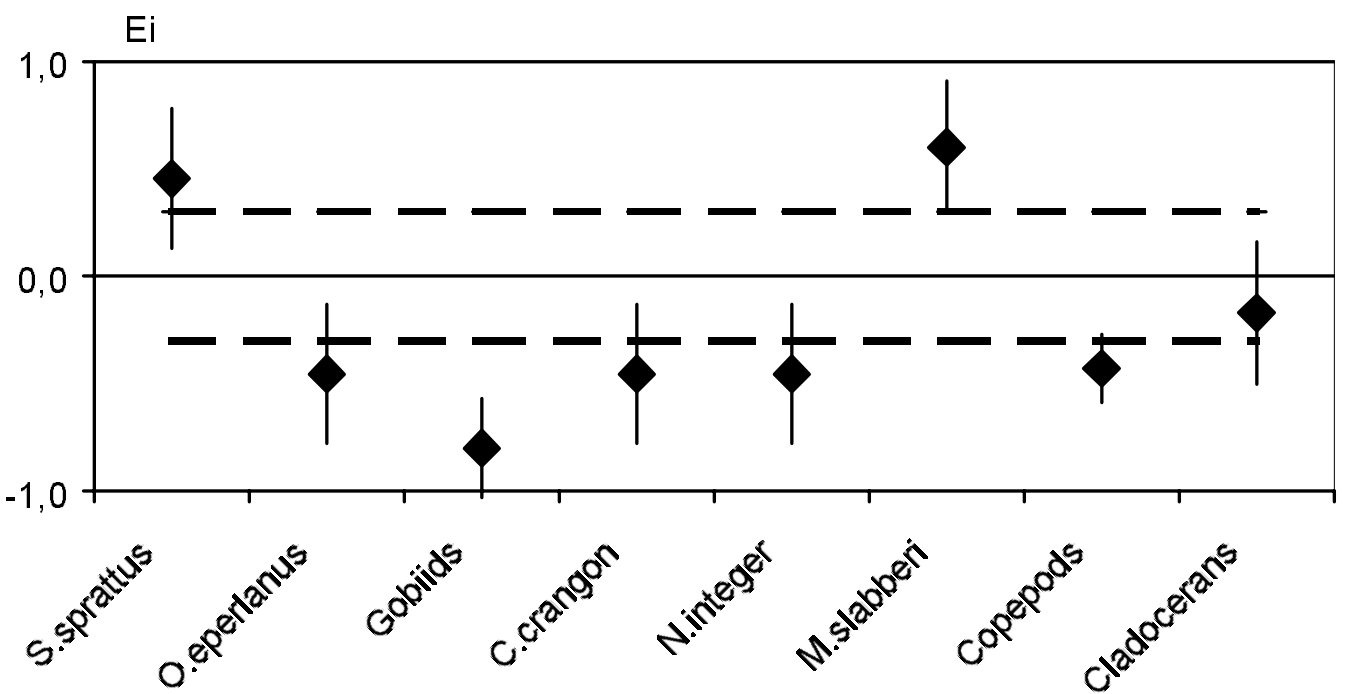

\section{Figure 5}

Daily mean of IVLEV's (1961) electivity (Ei) with regard to the main food items in the stomachs of age-0 twaite shad between $8^{\text {th }}$ and $9^{\text {th }}$ July 1993 ; Bars : confidence limits, broken lines : level of significance according to LAZZARO (1987).

\section{Figure 5}

Moyenne journalière d'index de sélection (Ei) d'après Ivlevs (1961) à partir de la composante alimentaire principale consommée entre le 8 et 9 juillet 1993 ; Colonne $=$ limite de confidence, Trait pointillé $=$ seuil de signification selon LAZZARO (1987).

\section{Daily Ration}

The seasonal course of daily rations of juvenile twaite shad was characterised by high values during spring and summer and a decreasing tendency in the following season (Figure 6). The maximum daily ration of about $45 \%$ of body wet weight was calculated in May 1992. The daily ration decreased with increasing age of fish.

The seasonal course of the size of the routine metabolism was similar to that of the daily ration with the same position of the maxima in May 1992 and minima in December 1992 (Figure 6). During summer the routine metabolism had a magnitude of approximately two third of the daily ration, while its contribution increased during winter.

A comparison of routine metabolism and daily ration of age group 0 twaite shad in 1992 and 1993 showed higher values in 1992 (Figure 6). This phenomenon was associated with higher mean water temperatures.

Unfortunately, it was not possible to compute daily rations with both the WINBERG (1956) and the EGGERS (1979) methods for overlapping time intervals (Table II). However, as close as possible intervals were used for the comparison of the daily rations calculated with both methods and showed only a slight difference of $0.32 \%$ (Table II). 


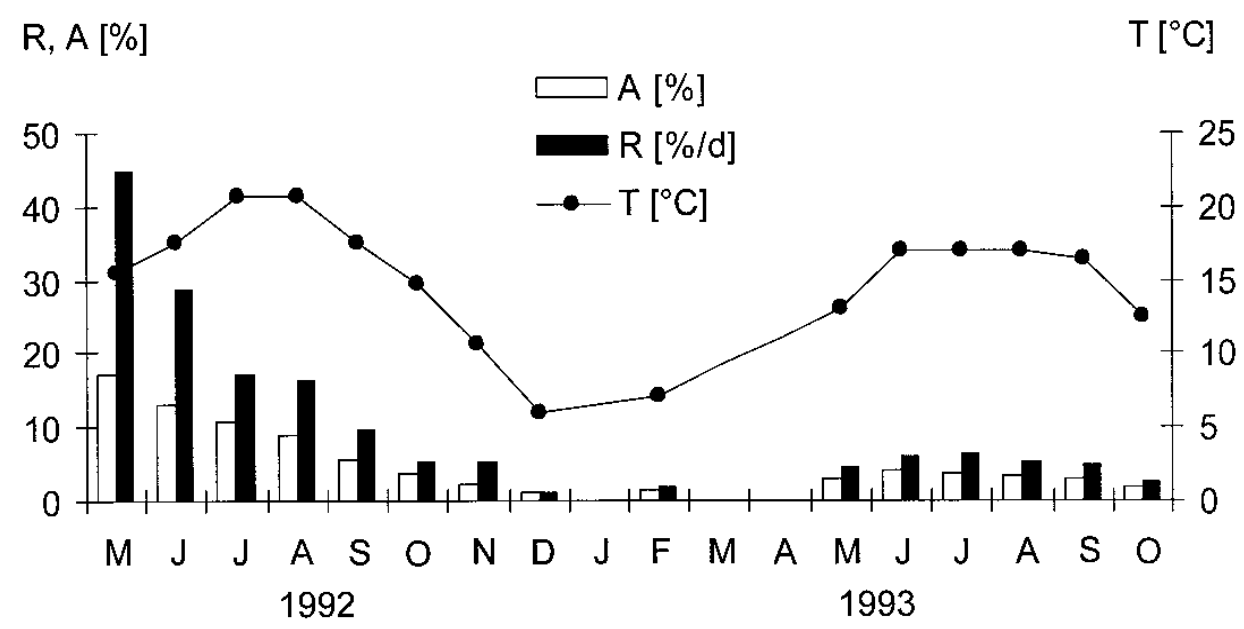

Figure 6

WINBERG's (1956) daily ration (R), routine metabolism (A) and mean water temperature $(T)$ for juvenile twaite shad of year class 1992 from May 1992 to October 1993.

\section{Figure 6}

Ration journalière $(R)$, métabolisme de routine $(A)$ et température de l'eau $(T)$ pour les juvéniles d'alose feinte de l'année 1992 calculés selon WINBERG (1956).

\section{Table II}

Daily rations (R) according to WINBERG (1956) and EGGERS (1979) for age-0 twaite shad in 1993 ; $\mathrm{A}=$ routine metabolism, $\mathrm{T}=$ water temperature, $\mathrm{Fi}=$ index of fullness, $\mathrm{Er}=$ evacuation rate.

\section{Tableau II}

Comparaison de la ration alimentaire journalière calculée selon WINBERG (1956) et EGGERS (1979) d'alose feinte de classe d'âge 0 ; $A$ = métabolisme de routine, $\mathbf{T}=$ température de l'eau, $\mathrm{Fi}=$ index de remplissage d'estomac, $\mathrm{Er}=$ taux d'évacuation.

\begin{tabular}{l|c|c|c} 
Time interval & Parameter & WINBERG (1956) & EGGERS (1979) \\
\hline 08 July - 09 July & $\mathrm{R}(\%)$ & - & 14.46 \\
& $\mathrm{~T}\left({ }^{\circ} \mathrm{C}\right)$ & - & 17.11 \\
& $\mathrm{Fi}(\%)$ & - & 2.42 \\
& $\mathrm{Er}$ & - & -0.25 \\
\hline 28 July - 25 August & $\mathrm{R}(\%)$ & 14.1 & - \\
& $\mathrm{A}(\%)$ & 6.7 & - \\
\hline 25 August - 14 September & $\mathrm{T}\left({ }^{\circ} \mathrm{C}\right)$ & 17.9 & - \\
& $\mathrm{R}(\%)$ & 6.8 & - \\
& $\mathrm{A}(\%)$ & 5.2 & - \\
\hline 14 September - 26 October & $\mathrm{T}\left({ }^{\circ} \mathrm{C}\right)$ & 16.6 & - \\
& $\mathrm{R}(\%)$ & 5.8 & - \\
& $\mathrm{A} \mathrm{( \% )}$ & 3.2 & - \\
& $\mathrm{T}\left({ }^{\circ} \mathrm{C}\right)$ & 12.5 & -
\end{tabular}




\section{DISCUSSION}

The food of the investigated juvenile twaite shad consisted mainly of copepods, mysids and fish. The seasonal composition of the food biomass changed from a dominant copepod proportion in spring (age group 1) via a dominant fish proportion in July (age group 0) to a major mysid share in late summer (age group 0). The food composition of age-0 juvenile twaite shad of the Elbe in August differed from those found by APRAHAMIAN (1989) in the british rivers Severn an Wye. APRAHAMIAN (1989) stated a low fish proportion and a high proportion of copepods in August. Mysids represented the higher biomass proportion in the food of juvenile twaite shad in british waters later in the year. However, the fact that fish could be an important food component of juvenile twaite shad in marine environments was also reported by BRACKEN and KENNEDY (1967) and WHEELER and DAVIES (1969). APRAHAMIAN (1989) explained the differences of those authors to his findings with a different availability of suitable prey in different waters and mentioned morphologic conditions as reasons for different prey utilization.

However, one reason for the seasonal change in food composition of juvenile twaite shad of age group 0 in the Elbe estuary is probably the increasing preference for larger pelagic prey during their ontogenetic development. The seasonal change of the food availability could be another reason. According to APRAHAMIAN (1989) the ontogenetic change of feeding preferences of twaite shad can be attributed to (i) the inability of this pelagic species for benthic food intake and (ii) the ineffective food search of twaite shad in it's environment or a higher energy demand by feeding copepods during the later juvenile stages.

HUTCHINSON (1971) found insects, plant material, rotifers, copepods and cladocerans as prey of juvenile $A$. pseudoharengus which is in tendencially agreement with the food composition of juvenile twaite shad from the Elbe estuary. The fact that A. pseudoharengus consumed insects and plant material like $A$. fallax in the Elbe estuary indicates an opportunistic feeding of both species. The non piscivorous feeding of A. pseudoharengus stated by HUTCHINSON (1971) could be due to the chosen sampling time, where fish larvae might not have been present. Additionally, this indicates the high importance of the food availability for the composition of the ingested prey of shads.

A change in the diurnal course of the food composition could have been caused by a changing feeding behaviour of twaite shad for different times of the day. Indicated by high number and biomass proportions of large food items, particulate feeding (LAZZARO, 1987) occurred almost exclusively during day. On the other hand, increasing copepod proportions from day until night showed a change in the feeding mode to filter feeding (LAZZARO, 1987) at night.

The seasonal electivity values for $A$. pseudoharengus provided by HUTCHINSON (1971) are of limited comparability to our findings, because no information is provided concerning the time of sampling or the variability of the food composition in the daily course. According to our estimations, positive selection of bosmids and avoidance of copepods which were reported by HUTCHINSON (1971), have presumably been received during day and could have been reversed at any other time of the day.

The maximum daily ration of young-of-the-year twaite shad estimated with the WINBERG (1956) method amounted to $45 \%$ of body wet weight at the beginning of the investigation period. Despite of several inaccuracies (THIEL, 2001) the WINBERG (1956) method provides advantages for the quantification of trophical relationships in ecosystems, especially if growth, abundance and temperature data are available over long periods of time (MANN, 1978). One advantage is the relatively low fishing effort. Even if the calculated consumption differs from the real one - a disadvantage which is also inherent in all other methods - it permits relative statements concerning the temporal and spatial 
course of the consumption especially over long periods of time. Furthermore, the possibility to verify the obtained consumption data with other methods exists (WOOTON, 1990). In this study, the EGGERS (1979) method was used for comparisons and, hence, produced similar values.

The highest daily rations of clupeids are known to occur in the larval phase and can even exceed the actual body weight. Furthermore, the daily ration is a function of temperature and depends from the prey density (BLAXTER and HUNTER, 1982). It decreases with increasing body weight at constant temperature. The maximum daily ration increases with increasing temperature to a peak at a preferred temperature (STEWART and BINKOWSKI, 1986). With further temperature increase the daily ration decreases to zero at the lethal temperature (ELLIOTT, 1976 ; BRETT, 1983). STEWART and BINKOWSKI (1986) calculated the preferred temperature for $A$. pseudoharengus. They found optimum temperatures between 24 and $25^{\circ} \mathrm{C}$ for age group 0 . Assuming a similar physiological condition for the investigated twaite shads, it can be supposed that the water temperature in the Elbe estuary in 1993 was far below the optimum temperature of this species. Finally, this means that higher daily rations of juvenile twaite shad could be expected at higher temperatures, especially if also higher food availabilities occur.

\section{ACKNOWLEDGEMENTS}

Many thanks to families Oesmann and Meyburg, the "Aktion seeklar » and the "Hansische Universitätsstiftung » for sponsoring our activities concerning twaite shad. We are also grateful to Britta Köpcke for the provision of unpublished plankton data, Eberhard Rübcke and Hein Neuman for the support of the fisheries, Jani und André for unpaid assistance during the 24-h-fishery. We also thank Prof. Dr. W. NELLEN, Prof. Dr. Ing. Carl «Amadeus » ENGEL and August HUBER for their help during this work.

\section{REFERENCES}

APRAHAMIAN M.W., 1989. The diet of juvenile and adult twaite shad Alosa fallax fallax (Lacépède) from the rivers Severn and Wye (Britain). Hydrobiologia, 179, 173-182.

ARRHENIUS F., HANSSON S., 1993. Food consumption of larval, young and adult herring and sprat in the Baltic Sea. Mar. Ecol. Prog. Ser., 96, 125-137.

ARGE ELBE, 1992. Salzgehalts und Trübstoffverhältnisse in dem oberen Brackwassergebiet der Elbe. Wassergütestelle Elbe, Juli 1992.

ASSIS C.A., ALMMEIDA P.R., MOREIRA F., COSTA J.L., COSTA M.J., 1992. Diet of the twaite shad Alosa fallax (Lacépède) (Clupeidae) in the River Tagus estuary, Portugal. J. Fish. Biol., 41, 1049-1050.

BLAXTER J.H.S., HUNTER J.R., 1982. The Biology of the Clupeoid Fishes. Adv. Mar. Biol., 20, 3-207.

BRACKEN J., KENNEDY M., 1967. Notes on some Irish estuarine and inshore fishes. Irish Fisheries Investigations Series B, 3, 4-8.

BRETT J.R., 1983. Life energetics of sockeye salmon, Oncorhynchus nerka in behavioural energetics. In : The cost of survival in vertebrates (ASPEY W.P. and LUSTICK S.I. Eds.), Ohio State Univ., Columbus, 29-63.

DIECKWISCH B., 1987. Die Verteilung der Fischbrut in der Unterelbe 1985. MSc Thesis, Christian-Albrechts-Universität, Kiel.

EGGERS D. M., 1979. Comments on some recent methods for estimating food consumption by fish. J. Fish. Res. Bd. Can., 36, 1018-1019.

EHRENBAUM E., 1894. Beiträge zur Naturgeschichte einiger Elbfische (Osmerus eperlanus L., Clupea finta Cuv., Acerina cernua L., Acipenser sturio L.). Wiss. Meeresunters. Helgol., 1, 54-63. 
ELLIOTT J.M., 1976. The energetics and feeding metabolism of brown trout (Salmo trutta L.) in relation to body weight, water temperature and ration size. Journal of Animal Ecology, 45, 923-948.

HARDING J.P., SMITH W.A., 1974. A Key to the British Freshwater Cyclopoid and Calanoid Copepods. Freshw. Biol. Ass., 18, 1-54.

HASS H., 1965. Untersuchungen über den Laichfischbestand der Elbfinte, Alosa fallax (Lacépède 1803), Archiv für Fischereiwissenschaft, XVI/2, 150-168.

HASS H., 1968. Untersuchungen über die vertikale und horizontale Verteilung der Eier der Finte, Alosa fallax (Lacépède 1803), in der Elbe, Archiv für Fischereiwissenschaft, XIX 1, 46-55.

HAY D.E., 1982. Effects of capture and fixation on gut contents and body size of pacific herring larvae. Rapp. P.-v. Réun. Cons. int. Explor. Mer., 178, 395-400.

HEWETT S.W., STEWART D.J., 1989. Zooplanktivory by alewifes in Lake Michigan: ontogenetic, seasonal, and historical pattern. Trans. Am. Fish. Soc., 118, 581-596.

HUTCHINSON B.P., 1971. The effect of fish predation on the zooplankton of ten Adriondack lakes, with particular reference to the alewife, Alosa pseudoharengus. Trans. Am. Fish. Soc., 2, 325-335.

IVLEV V.S., 1961. Experimental ecology of the feeding of fishes. Yale Univ. Press. New Haven. $302 \mathrm{p}$.

JANSEN W., 1985. Stellung von Neomysis integer Leach (Crustacea, Mysidacea) als Konsument im Nahrungsgefüge der Darß-Zingster Boddenkette (südl. Ostsee). Fischerei-Forsch., 23, 55-59.

KIEFER F., FREYER G., 1978. Das Zooplankton der Binnengewässer 2. Teil. Die Binnengewässer, Stuttgart. 380 p.

KIES L., NEUGEBOHRN L., BRAKER H., FAST T., GAETJE C., 1992. Primärproduzenten und Primärproduktion im Elbe-Ästuar, Berichte aus d. Zentrum $f$. Meeres- $u$. Klimaforschung d. Universität Hamburg, 19, 137-168.

KLAUSNITZER B., JACOB U., JARISCH O., JOOST W., KLIMA F., PETERS G., 1978. Wasserinsekten. Kulturbund d. DDR, $87 \mathrm{p}$.

KÖPCKE B., KAUSCH H., 1996. Distribution and variability in abundance of Neomysis integer and Mesopodopsis slabberi (Mysidacea ; Crustacea) in relation to environmental factors in the Elbe estuary. Arch. Hydrobiol. Suppl., 110, 263-282.

KROGH A., 1916. Respiratory exchange of animals and man. LONGMANNS, GREEN \& Co., London.

LAZZARO X., 1987. A review of planktivorous fishes: Their evolution, feeding behaviours, selectivities and impacts. Hydrobiologia, 146, 97-167.

MANN K.H., 1978. Estimating the food consumption of fish in nature : Ecology of freshwater fish production (ed. GERKING S.D.), Oxford, Blackwell, 250-273.

MEHNER T., 1990. Zur Bestimmung der Beutefischarten aus Fragmenten der Wirbelsäule bei der Nahrungsanalyse (Osteichthyes, Teleostei). Zool. Anz., 225, 3/4, 210-222.

MUUS B.J., DAHLSTRÖM P., 1965. Meeresfische. BLV Verlagsgesellschaft $\mathrm{mbH}$, München, Wien, Zürich.

NELLEN W., SCHNACK D., ZEITSCHEL, 1987. Expeditionsbericht über die METEORReise 5 Abschnitt 3, Berichte aus d. Zentrum $f$. Meeres- und Klimaforschung $d$. Univ. Hamburg, 0, 155-156.

OESMANN S., 1994. Nahrung und Wachstum clupeider Fische in der Unterelbe, MSc Thesis, Universität Hamburg, 95 p.

PALUSKA A., 1992. Geographie und geologische Vorgeschichte der norddeutschen Ästuare, erläutert am Beispiel der Elbe, Berichte aus d. Zentrum f. Meeres- $u$. Klimaforschung d. Universität Hamburg, 19, 1-32.

REINCKE H., LISCHKE P., SCHINDLER J., 1992. Vorstellung der Ergebnisse der Arbeitsgruppe «Meß- und Untersuchungsprogramme » der Internationalen Kommission zum Schutz der Elbe. Tagungsband des 4. Magdeburger Gewässerschutzseminars zur Situation der Elbe, 275-282.

SCOURFIELD D.J., HARDING J.P., 1966. A Key to the British Species of Freshwater Cladocera. Freshw. Biol. Assoc., 5, 1-55. 
SMITH, D.L., 1977. A Guide to Marine Coastal Plankton and Marine Invertebrate Larvae. Kendall / Hunt, lowa, 150 p.

STEWART D.J., BINKOWSKI F.P., 1986. Dynamics of Consumption and Food Conversion by Lake Michigan Alewives: An Energetics-Modeling Synthesis. Trans. Am. Fish. Soc., 115, 643-661.

STRESEMANN E., 1986. Exkursionsfauna für die Gebiete der DDR und BRD, Bd. 2 / 1, Wirbellose, Insekten, Volk und Wissen Volkseigener Verlag Berlin.

THIEL R., 2001. Spatial gradients of food consumption and production of juvenile fish in the lower River Elbe. Arch. Hydrobiol. Suppl., 135, 441-462.

THIEL R., MEHNER T., KÖPCKE B., KAFEMANN R., 1996. Diet niche relationships among early life stages of fish in German estuaries. Mar. Freshwater Res., 47, 123136.

THIEL R., POTTER I., 2001. The ichthyofaunal composition of the Elbe estuary : an analysis in space and time. Marine Biology, 138 (3), 603-616.

THIEL R., SEPULVEDA A., KAFEMANN R., NELLEN W., 1995. Environmental factors as forces structuring the fish community of the Elbe estuary. J.Fish Biol., 46, 47-69.

THIEL R., SEPULVEDA A., OESMANN S., 1996. Occurrence and distribution of twaite shad (Alosa fallax Lacépède) in the lower Elbe River, Germany. In : Conservation of Endangered Freshwater fish in Europe (Eds. KIRCHHOFER A. and HEFTI D.), Birkhaeuser-Verlag, Basel-Switzerland, 157-170.

WHEELER C.E., DAVIES G.E., 1969. The fishes of the British Isles and Northwest Europe. London: MacMillan.

WINBERG G.G., 1956. Rate of metabolism and food requirements of fish. Fish. Res. Bd. Can. Transl. Ser., 194, 1-202.

WOOTTON R.J., 1990. Ecology of Teleost Fishes. Chapman and Hall, London. 